\title{
Nondestructive Microstructural Characterization of Superduplex Stainless Steel by Double Loop Electrochemical Polarization Reactivation Portable Test
}

\author{
Tatiana Resende Alvarez, Juan Manuel Pardal ${ }^{a, b} *$ Brígida Bastos de Almeida ${ }^{a}$, Pablo Louzada $^{a}$, \\ Sérgio Souto Maior Tavares ${ }^{a, b}$, Eduardo Ariel Ponzio $^{c}$, Marcelo Camargo Severo de Macedo \\ aProgramas de Pós-Graduação em Engenharia Mecânica - PGMEC e Montagem Industrial, \\ Universidade Federal Fluminense, Rua Passo da Pátria, 156, CEP 24210-240, Niterói, RJ, Brazil \\ ${ }^{b}$ Programa de Pós-Graduação em Engenharia Mecânica e Tecnologia de Materiais, Centro Federal de \\ Educação Celso Suckow, Rio de Janeiro, RJ, Brazil \\ 'Departamento de Físico-Química, Programa de Pós-Graduação em Química, Universidade Federal \\ Fluminense, Rua Outeiro de São João Batista s/n, CEP 24020-141, Niterói, RJ, Brazil \\ ${ }^{d}$ Departamento de Engenharia Mecânica. Programa de Pós-Graduação em Engenharia Mecânica, \\ Universidade Federal do Espírito Santo, Rua Av Fernando Ferrari s/n, CEP 29060-970, Vitória, ES, \\ Brazil
}

Received: December 11, 2016; Revised: May 01, 2017; Accepted: September 15, 2017

\begin{abstract}
Superduplex stainless steels (SDSS) are frequently employed in the petrochemical industries where is required high mechanical strength, toughness, and corrosion resistance. However, these properties can be affected by deleterious phases formation due thermomechanical processes applied in the field during pipes and vessels construction. This work propose the nondestructive microstructural characterization of deleterious phases precipitated in SDSS isothermally treated in 800 and $850^{\circ} \mathrm{C}$ using portable double loop electrochemical polarization reactivation tests (DL-EPR). The results obtained in this nondestructive test are quite close to those obtained by conventional test, and can be correlated with the amount of deleterious phases precipitated. It can be concluded that the microstructural degradation of superduplex stainless steel can be evaluated by portable DL-EPR test with slow sweep rates, using a special cell and a proper electrolyte at room temperature.
\end{abstract}

Keywords: Superduplex stainless steel, Deleterious phases precipitation, DL-EPR portable test, Microstructural characterization.

\section{Introduction}

Duplex (DSS) and superduplex (SDSS) stainless steels are materials frequently used in the chemical and petrochemical industries, due to the high mechanical and corrosion resistance ${ }^{1}$. However, these stainless steels (SS) can undergo problems due to deleterious phases precipitation, due to manufacturing processes and/or aging in service ${ }^{2-3}$. SDSS are more susceptible to deleterious phases precipitation, such as $\sigma$ and $\chi$, when compared with DSS, because of higher $\mathrm{Cr}$ and Mo contents. Small quantities of these phases in the microstructure decrease dramatically the toughness and the corrosion resistance without produce significant changes in the hardness values of DSS and SDSS ${ }^{1-3}$. Sigma phase $(\sigma)$ can be formed by slow continuous cooling ${ }^{3-4}$ or by isothermal treatment with greater kinetics in the $800-850^{\circ} \mathrm{C}$ range ${ }^{1,5}$. For these reasons, is interesting to characterize SDD and SDSS by double loop electrochemical polarization reactivation test (DL-EPR) to determinate the degree of sensitization (DOS) and consequently the susceptibility to deleterious phases precipitation.

*e-mail: juanpardal@vm.uff.br
Lopez et al. ${ }^{6}$ analyzed the influence of $\sigma$ phase precipitation on the corrosion resistance of a DSS UNS S31803 aged at $675^{\circ} \mathrm{C}$ and $900^{\circ} \mathrm{C}$ by DL-EPR testing using a $2.00 \mathrm{M} \mathrm{H}_{2} \mathrm{SO}_{4}$ $+0.01 \mathrm{M} \mathrm{KSCN}+0.50 \mathrm{M} \mathrm{NaCl}$ solution at $30^{\circ} \mathrm{C}$. These authors considered the material susceptible to intergranular corrosion when the degree of sensitization (DOS = Ir/Ia) was higher than 0.05 .

Recently, some papers ${ }^{7-8}$ covered the use of portable cells to deleterious phases characterization in SDSS. Barreto et al. ${ }^{7}$ employed a solution with $2.00 \mathrm{M} \mathrm{H}_{2} \mathrm{SO}_{4}+0.01 \mathrm{M} \mathrm{KSCN}+$ $1.00 \mathrm{M} \mathrm{NaCI}$ and performed the DL-EPR test with scan rates between 1.5 and $3.0 \mathrm{mV} / \mathrm{s}$ in situ. They observed that the DOS was sensitive to deleterious phases in amounts above $8.00 \%$. On the other hand, Assis et al. ${ }^{8}$ performed tests with $3 \mathrm{M} / \mathrm{dm}^{3} \mathrm{HCl}$ solution and scan rate $0.56 \mathrm{mV} / \mathrm{s}$. They found that the $\delta / \gamma$ ratio and the distribution of austenite islands in ferrite matrix exert great influence on the DOS results.

In a previous work, Pardal et al. ${ }^{9}$ evaluated the effects of isothermal aging in a SDSS UNS S32750, with different grain sizes, by DL-EPR. It was employed a solution with $2.00 \mathrm{M} \mathrm{H}_{2} \mathrm{SO}_{4}+0.01 \mathrm{M} \mathrm{KSCN}+0.50 \mathrm{M} \mathrm{NaCI}$ at $40^{\circ} \mathrm{C}$ in the conventional destructive method. 
This work is distinguished by characterizing the incipient presence of deleterious phases in SDSS S32750 through the use of DL-EPR technique with a portable cell. The electrolyte was optimized in order to perform the tests at room temperature.

The use of non-destructive technique by electrochemical characterization can promote great benefits in determining the degree of microstructure deterioration of SDSS. The results indicate that this technique can be applied to study the microstructural changes in the tested material, and can be used as an important non-destructive test in the field.

\section{Experimental}

Two types of UNS S32750 SDSS were studied, identified as "SD-A" and "SD-B". SD-A is a seamless tube and SD-B is a round bar. Table 1 shows that the chemical composition of the two materials are similar.

Table 2 shows the phase proportions, as well as the grain size corresponding to ferrite $(\delta)$ and austenite $(\gamma)$ in the solution treatment condition for each material. Although the chemical composition of both products are similar, the differences of the phases and precipitated grain sizes between the SD-A and SD-B may be attributed to differences of processing of these materials.

Isothermal treatments at 800 and $850^{\circ} \mathrm{C}$ for $5,15,30$, 45, 60 and 90 minutes were performed in SD-A and SD-B samples. These treatments introduced different amounts of deleterious phases in the microstructure. These samples were characterized metallographic by light optical microscopy (LOM) using electrochemical $\mathrm{KOH}$ reagent to reveal the deleterious phases. The deleterious phases precipitated revealed by LOM were quantified with Image Tools software ${ }^{10}$ analyzing 20 fields per condition. The percentages of deleterious phases precipitated were used, in this work, as a basis for evaluating the results obtained in the DL-EPR conventional and portable methods.

The DL-EPR tests were conducted with natural aeration at room temperature in solutions predetermined to characterize the initial formation of deleterious phase precipitation. Conventional DL-EPR tests were performed in the laboratory using a potentiostat galvanostat $\mu$ Autolab $^{\circledR}$ Type 3 shown in Figure 1, with a cell containing three electrodes ${ }^{9}$. The area exposed to the electrolyte was a square with $1.0 \mathrm{~cm}^{2}$, and the volume of solution was $250 \mathrm{~mL}$. In these tests, the scan was started, approximately thirty minutes, after the potential stabilization with open circuit $\left(\sim 0.4 \mathrm{~V}_{\mathrm{SCE}}\right)$. Then, the potential measured in relation to reference electrode was increased with a rate of $1 \mathrm{mV} / \mathrm{s}$ in the anodic direction until $0.3 \mathrm{~V}_{\mathrm{SCE}}$. Finally, at this point, the sweep was reversed to the cathodic direction toward the original value of the open circuit potential.

The loss of corrosion resistance due to chromium poor regions was evaluated by two methods. The first one is related to the ratio of the reactivation current peak (Ir) and activation current peak (Ia) in the anodic sweep, i.e., the ratio Ir/Ia. The second methodology proposed, referring to the ISO 12732 standard ${ }^{11}$, evaluates the degree of sensitization from the ratio Qr/Qa, where Qa is the integrated current under the peak over the time in the anodic scan and Qr is the integrated current under the peak over the time observed in the reversed scan. The second methodology was proposed due to the appearance of several activation and reactivation peaks in some aged conditions.

The non-destructive and portable tests were conducted using the same potentiostat, parameters and methodology applied to determine the degree of sensitization with the conventional cell. For practical purpose, the apparatus of $\mu$ Autolab ${ }^{\circledR}$ potentiostat with a notebook can be transported and assembled in the field, although smaller and lighter potentiostats models are available for sale in nowadays. The portable cell body was made from a PET commercial tube before blow molding bottle. This cell is very low cost and easy to manufacture ${ }^{12}$. In Figure 2 is observed a schematic design of the portable cell, while Figure 3 shows DL-EPR portable test being performed using saturated calomel electrode as reference and a $\mathrm{Pt}$ wire as counter electrode, just as in the conventional tests. In the portable test, the area exposed to the electrolyte was a circle with 3 mm of diameter $\left(0.07 \mathrm{~cm}^{2}\right)$ and the volume of solution was approximately $8 \mathrm{~mL}$.

Table 1. Chemical composition of the SDSS analysed.

\begin{tabular}{|c|c|c|c|c|c|c|c|c|c|c|c|c|}
\hline \multirow{2}{*}{ Material } & \multirow{2}{*}{ Classification } & \multicolumn{11}{|c|}{ Chemical composition \%wt. (\%Fe=balance) } \\
\hline & & $\mathrm{Cr}$ & $\mathrm{Ni}$ & Mo & Mn & $\mathrm{Si}$ & $\mathrm{N}$ & $\mathrm{Cu}$ & W & $\mathrm{C}$ & $\mathrm{P}$ & $\mathrm{S}$ \\
\hline SD-A & UNS S32750 & 24.57 & 6.68 & 3.75 & 0.83 & 0.34 & 0.28 & 0.25 & --- & 0.02 & 0.03 & --- \\
\hline SD-B & UNS S32750 & 24.80 & 6.75 & 3.79 & 0.78 & 0.54 & 0.27 & 0.10 & 0.04 & 0.02 & 0.03 & 0.001 \\
\hline
\end{tabular}

Table 2. Phases Proportions and grain sizes of SDSS studied.

\begin{tabular}{cccccccc}
\hline \multirow{2}{*}{ Material } & \multicolumn{3}{c}{ Ferrite $(\delta)$} & \multicolumn{3}{c}{ Austenite $(\gamma)$} \\
\cline { 2 - 8 } & Amount & \multicolumn{2}{c}{ Grain Size } & Amount & \multicolumn{2}{c}{ Grain Size } \\
\cline { 2 - 8 } & $(\%)$ & $(\mu \mathrm{m})$ & ASTM N $^{\circ}$ & $(\%)$ & $(\mu \mathrm{m})$ & ASTM N $^{\circ}$ \\
\hline SD-A & 55.05 & 29.42 & 12.1 & 44.95 & 24.75 & 12.3 \\
SD-B & 49.95 & 132.36 & 9.9 & 50.05 & 138.32 & 9.9 \\
\hline
\end{tabular}




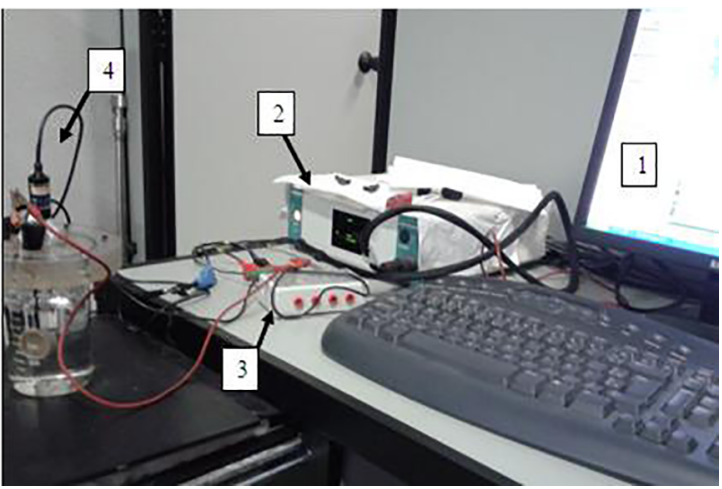

Figure 1. Potentiostat galvanostat $\mu$ Autolab $^{\circledR}$ Type III. 1- Computer; 2- Potentiostat; 3- Dummy cell; 4- Conventional cell.

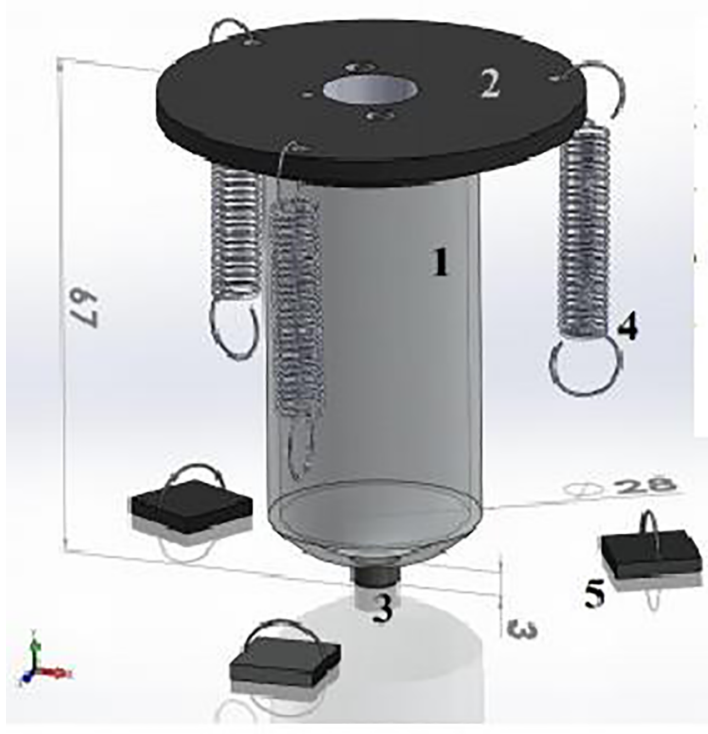

Figure 2. Schematic design of portable cell. 1- Cell body, 2- Cover, 3- O'ring, 4- Fixing springs, 5- Velcro feets. Dimensions in mm.

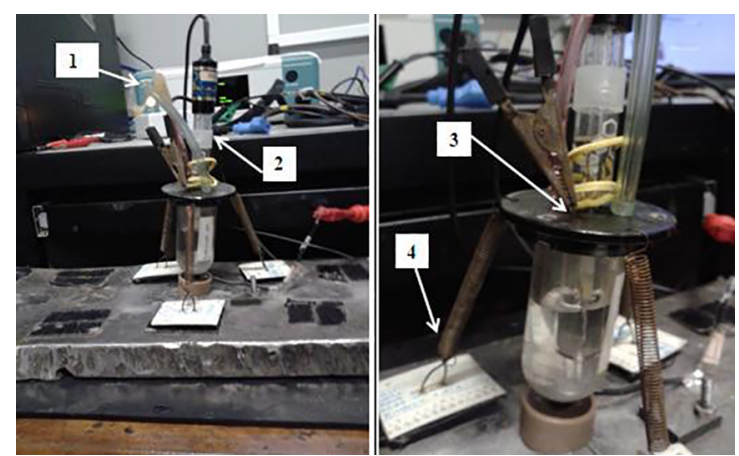

Figure 3. Portable DL-EPR test method. 1- Potentiostat galvanostat $\mu$ Autolab $^{\circledR}$ Type III; 2- Saturated calomel electrode; 3- Counter electrode, 4- Fixation of portable electrochemical cell.

After performing the DL-EPR tests by portable method, the areas evaluated by this technique were characterized by LOM for the purpose of reveal the deleterious phases precipitated and to correlate with the results found with conventional DL-EPR tests.

\section{Results}

Conventional DL-EPR tests were initially performed in the SD-A as received and isothermally treated at $800^{\circ} \mathrm{C}$ for 15 minutes. In this treatment condition there was approximately $9 \%$ of deleterious phases. Preliminary DL-EPR tests were performed with different solutions in order to find the most appropriate solution at room temperature. The solution should provide high sensitivity to the test, and also produce a test without reactivation peak for the solution treated specimen. After several tests, the solution containing $2.5 \mathrm{M} \mathrm{H}_{2} \mathrm{SO}_{4}+$ $0.02 \mathrm{M} \mathrm{KSCN}+1.0 \mathrm{M} \mathrm{NaCl}$ resulted in a clearly reactivation peak (Figure 4) in the aged specimen, and no reactivation peak in the as received (un-aged) material. This solution was adopted in conventional and portable tests.

Figure 5 shows the variation of the $\mathrm{Ir} / \mathrm{Ia}$ and $\mathrm{Qr} / \mathrm{Qa}$ with aging time at $800^{\circ} \mathrm{C}$, using the portable cell for SD-A and SD-B. Ir/Ia and Qr/Qa results show the same tendency and are very reproducible. Similar results were obtained for the others analyzed conditions by portable and conventional method, as reported ${ }^{9}$. Nevertheless, can be observed a greater degree of sensitization in SD-A (Figure 5(a)), when compared with same condition of SD-B (Figure $5(\mathrm{~b})$ ). This different behaviour of SD-A and SD-B is due to the smaller grain size of SD-A which accelerates the precipitation kinetics ${ }^{3-4}$.

Figure 6 compares the $\mathrm{Qr} / \mathrm{Q}$ a ratios in the conventional and portable DL-EPR tests with the percentage of deleterious phases precipitated of the SD-A samples isothermally treated at $800^{\circ} \mathrm{C}$. In the early stages of isothermal treatment from Figure 6(a) it was observed a sensitivity to deleterious phases precipitation with a slightly increase of $\mathrm{Qr} / \mathrm{Qa}$ ratios. In portable tests a ratio $\mathrm{Qr} / \mathrm{Qa}=0.04$ was measured with $4.0 \%$ of deleterious phases, produced with 5 minutes of isothermal treatment. In accordance to Figure 6(b), the

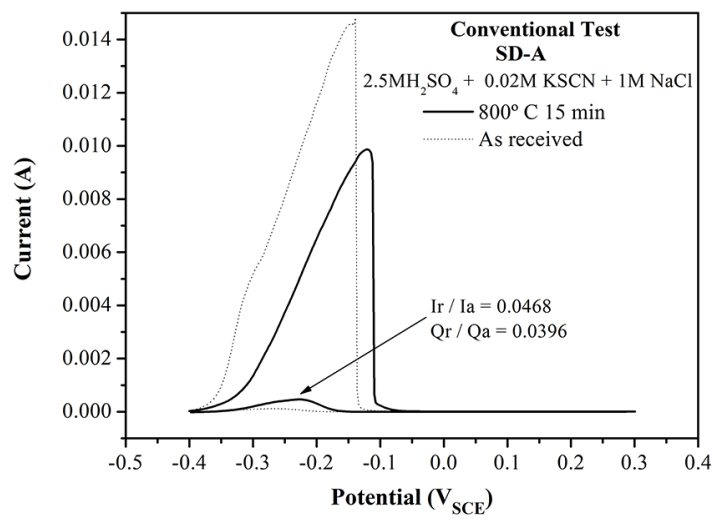

Figure 4. DL-EPR conventional tests in SD-A as received and aged at $800^{\circ} \mathrm{C}$ for 15 minutes performed with $2.5 \mathrm{M} \mathrm{H}_{2} \mathrm{SO}_{4}+0.02$ $\mathrm{M} \mathrm{KSCN}+1.0 \mathrm{M} \mathrm{NaCl}$ solution at room temperature. 

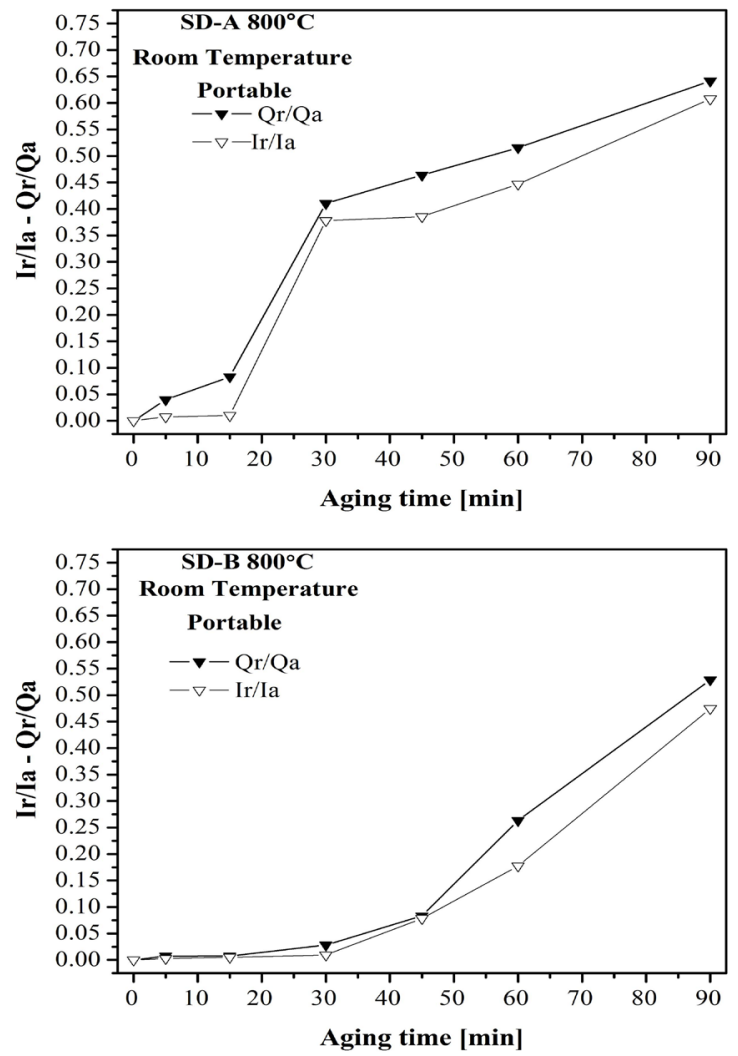

Figure 5. Ir/Ia and Qr/Qa ratio values in portable DL-EPR tests at room temperature in the samples (a) SD-A and (b) SD-B aged at $800^{\circ} \mathrm{C}$.

increase of Qr/Qa ratio is more intense than the increase of deleterious phases for aging times greater than 15 minutes.

Figure 7 compares the variation of Qr/Qa ratio in the conventional and portable DL-EPR tests with the percentage of deleterious phases in SD-A samples aged at $850^{\circ} \mathrm{C}$. In the early stages of precipitation (Figure 7(a)), the sample treated for 15 minutes presented $12 \%$ of deleterious phase and Qr/ $\mathrm{Qa}=0.03$. The metallographic characterization performed after DL-EPR test, shown in Figure 8(a), reveals sites of intergranular corrosion, mainly in $\delta / \gamma$ interfaces. These are the regions were $\sigma$ phase precipitates, as shown with more details in Figure 8(b).

According to the data presented in Figures 6 and 7 the Qr/ Qa values measured with portable and conventional methods in SD-A samples are not always coincident. However, they show the same tendency of variation with the deleterious phase precipitation. In general, except for some points in the specimen aged at $850^{\circ} \mathrm{C}$, the values measured with the portable method are slightly superior to the conventional method. The reasons for such discrepancy may be further investigated, but can be related to the different volume of electrolyte and area exposed in the two types of test.
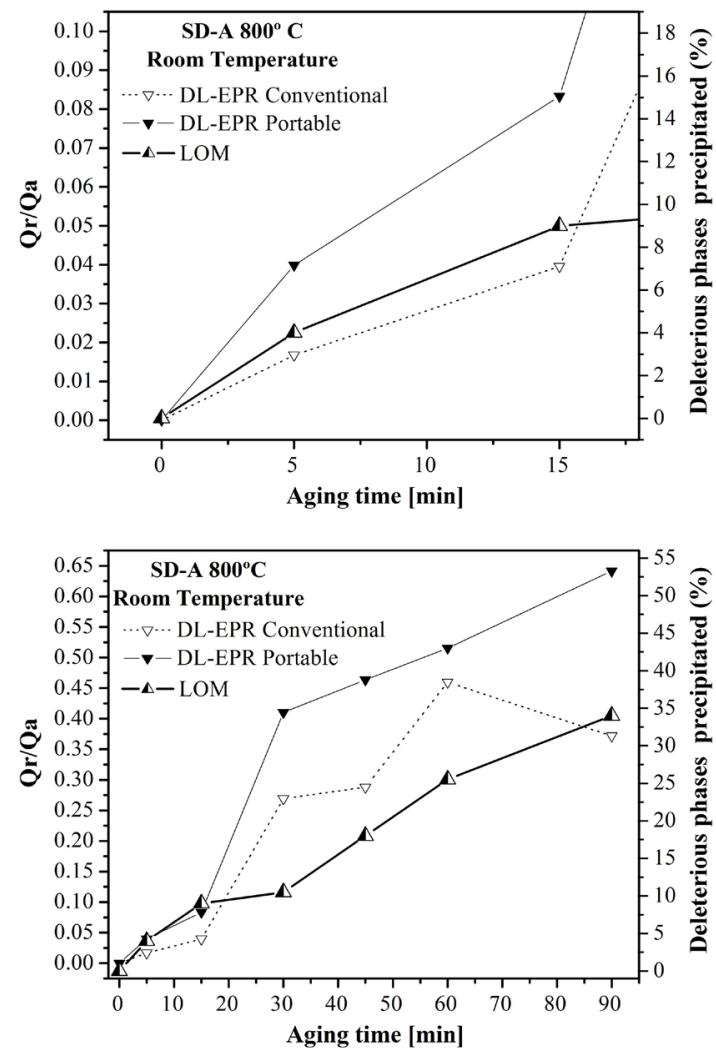

Figure 6. Qr/Qa ratios and deleterious phases precipitated percentage against aging time in SD-A samples aged at $800^{\circ} \mathrm{C}$ till (a) 15 minutes and (b) 90 minutes.

A comparative analysis between Figure 6(b) and 7(b) indicates that the precipitation kinetics at $850^{\circ} \mathrm{C}$ in $\mathrm{SD}-\mathrm{A}$ is slightly greater than at $800^{\circ} \mathrm{C}$ and the same behaviour was confirmed in the Qr/Qa for long aging times. The images shown in Figs 9(a-b) are partially defocussed because the specimen was not perfectly flat and the preparation could not be improved after the DL-EPR test. Nevertheless, it is possible to observe in the focused areas the sigma phase $(\sigma)$ and secondary austenite $\left(\gamma_{2}\right)$ formation by lamellar eutectoid decomposition of ferrite $(\delta)$, which explains the high $\mathrm{Qr} /$ Qa ratio measured.

Figure 10 compares the Qr/Qa variation in conventional and portable DL-EPR tests with the percentage of deleterious phases precipitated of the SD-B samples aged at $800^{\circ} \mathrm{C}$. As shown in Figure 10(a), the deleterious phases precipitated and the Qr/Qa ratios remains with low values, because the coarser grains delays the precipitation kinetics in comparison to SD-A steel. These facts are corroborated by the LOM analysis of specimen aged at $800^{\circ} \mathrm{C}$ for 15 minutes (Figure 11), where it was not observed intergranular corrosion sites. Figure 10 (b) shows that a ratio of $\mathrm{Qr} / \mathrm{Qa}=0.08$ in portable test was attained when $5.5 \%$ of deleterious phases precipitated during 

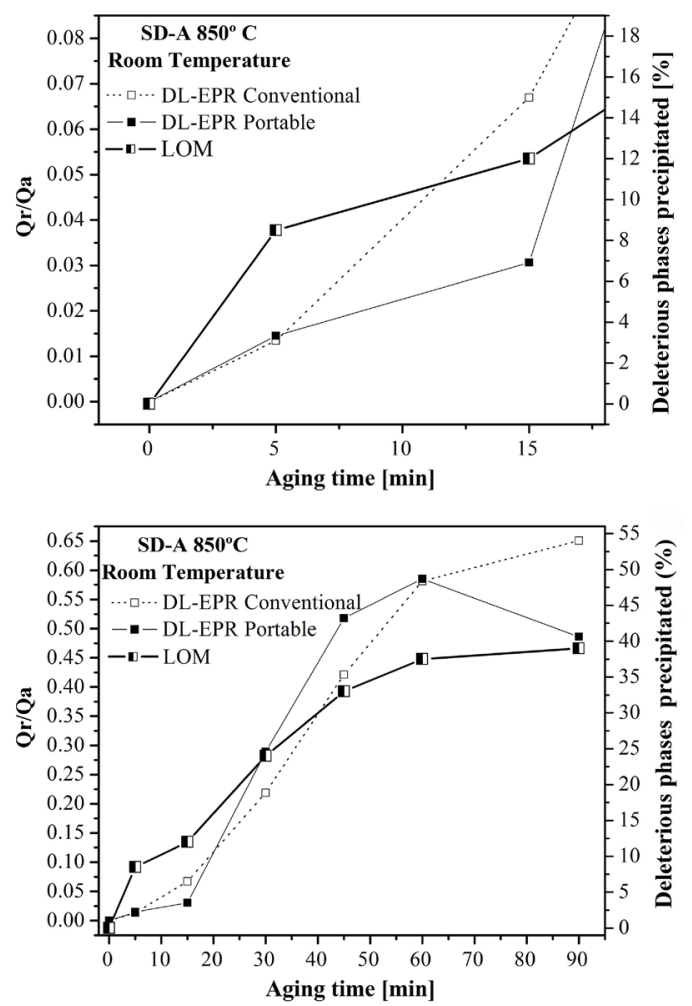

Figure 7. Qr/Qa ratios and deleterious phases precipitated percentage against aging time in SD-A samples aged at $850^{\circ} \mathrm{C}$ till (a) 15 minutes and (b) 90 minutes.
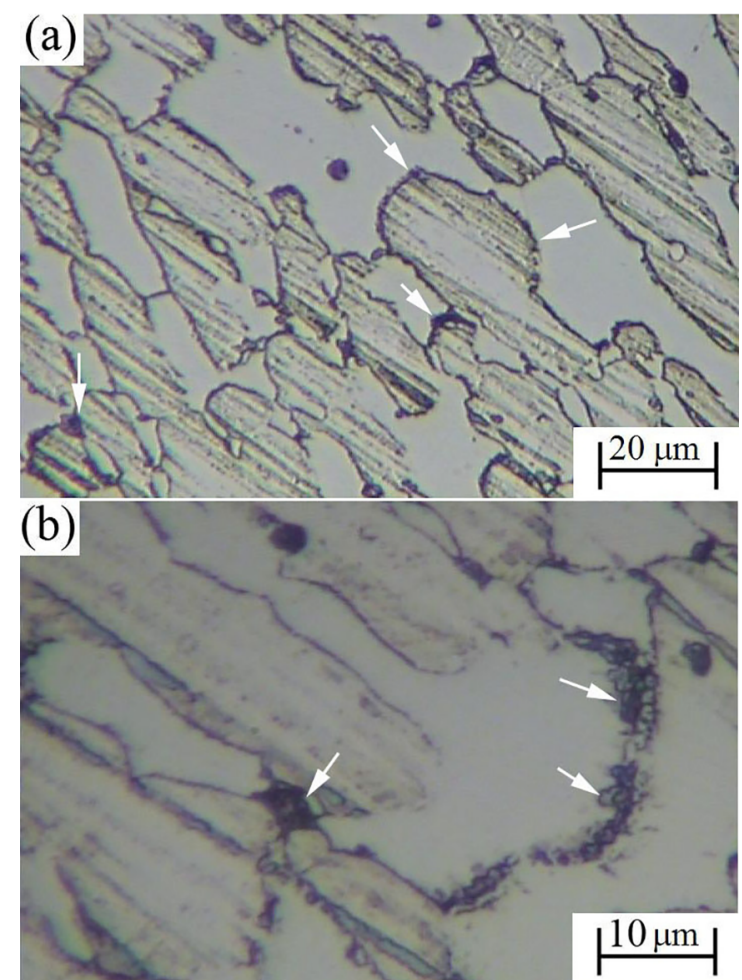

Figure 8. Microstructures obtained after portable DL-EPR test performed at room temperature in SD-A material aged at $850^{\circ} \mathrm{C}$ for 15 minutes.
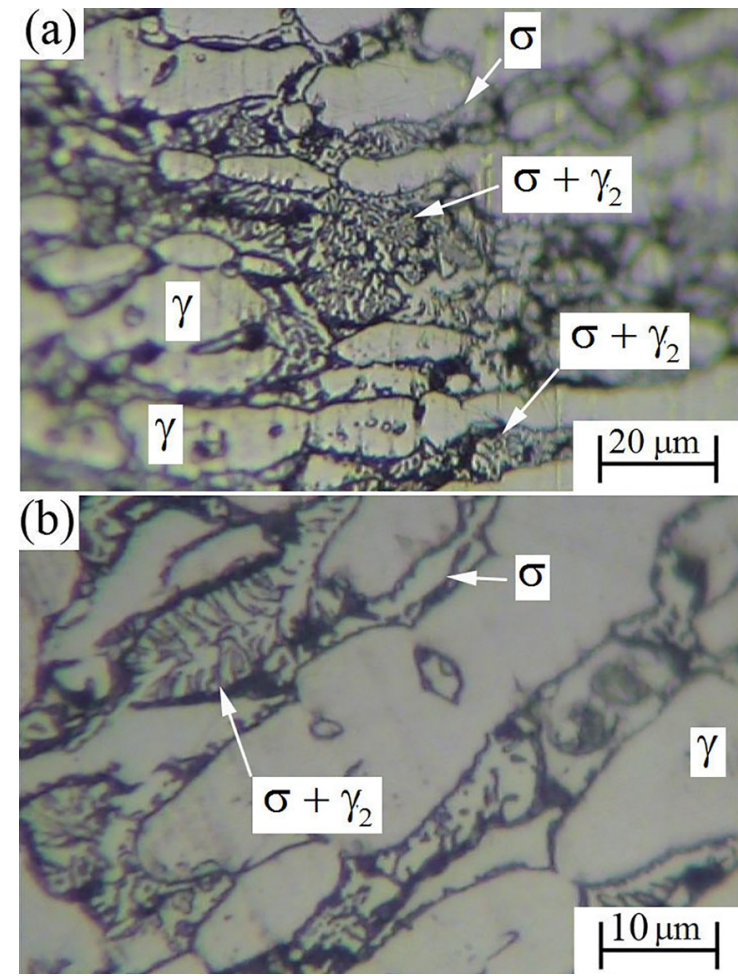

Figure 9. Microstructures obtained after portable DL-EPR test performed at room temperature in SD-A material aged at $850^{\circ} \mathrm{C}$ for 45 minutes.
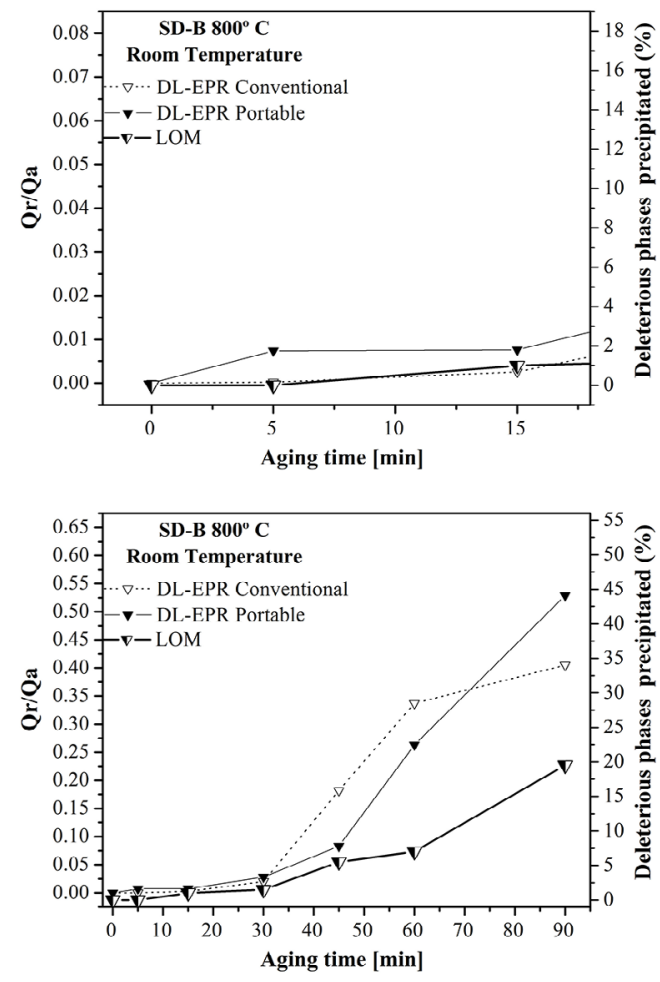

Figure 10. Qr/Qa ratios and deleterious phases precipitated percentage against aging time in SD-B samples aged at $800^{\circ} \mathrm{C}$ till (a) 15 minutes and (b) 90 minutes. 


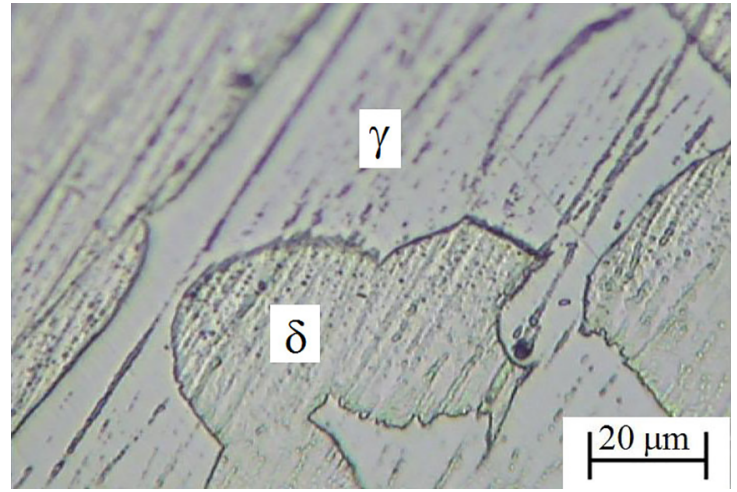

Figure 11. Microstructure obtained after portable DL-EPR test performed at room temperature in SD-B material aged at $800^{\circ} \mathrm{C}$ for 15 minutes.

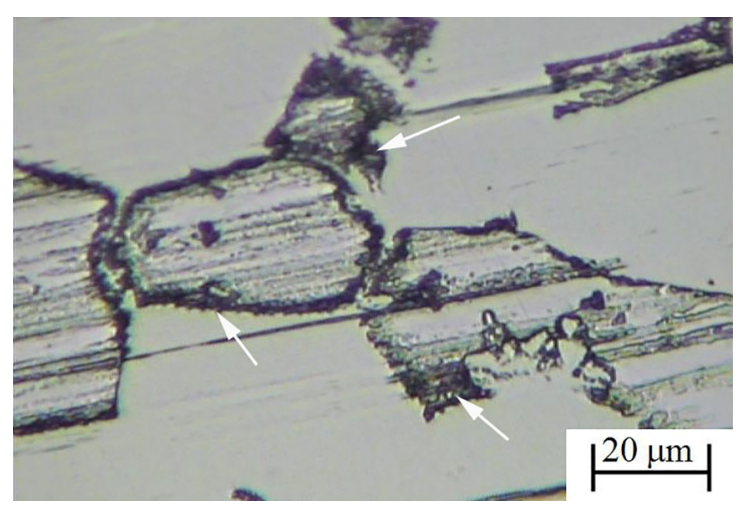

Figure 12. Microstructure obtained after portable DL-EPR test performed at room temperature in SD-B material aged at $800^{\circ} \mathrm{C}$ for 45 minutes.

45 minutes of aging. In accordance, this sample showed intergranular corrosion when observed by LOM by white arrows in Figure 12. It can be also seen that the $\mathrm{Qr} / \mathrm{Qa}$ is very sensitive to deleterious phases precipitation for greater aging times, such as observed in Figure 8(b).

Figure 13 compares the behaviour of $\mathrm{Qr} / \mathrm{Qa}$ in the conventional and portable DL-EPR tests in SD-B samples isothermally treated at $850^{\circ} \mathrm{C}$. The results are similar to those presented for SD-B aged at $800^{\circ} \mathrm{C}$. Figure 13(a) shows that the amount of deleterious phases precipitated and the Qr/Qa ratios remains low, although the kinetics of precipitation at $850^{\circ} \mathrm{C}$ is more intense than at $800^{\circ} \mathrm{C}$, as shown in Figure 13(b). This same trend was obtained with portable DL-EPR test. The specimen aged for 30 minutes had $16.5 \%$ of deleterious phase and $\mathrm{Qr} / \mathrm{Qa}=0.48$. Figure 14 shows the surface of specimen after DL-EPR, with dark corroded areas indicated by arrows in the grain boundaries and inside the ferrite decomposed into austenite and $\sigma$ phase.

In general, the differences between the Qr/Qa values measured with conventional and portable methods in SD-B were lower than in SD-A, mainly in the initial stages of precipitation.
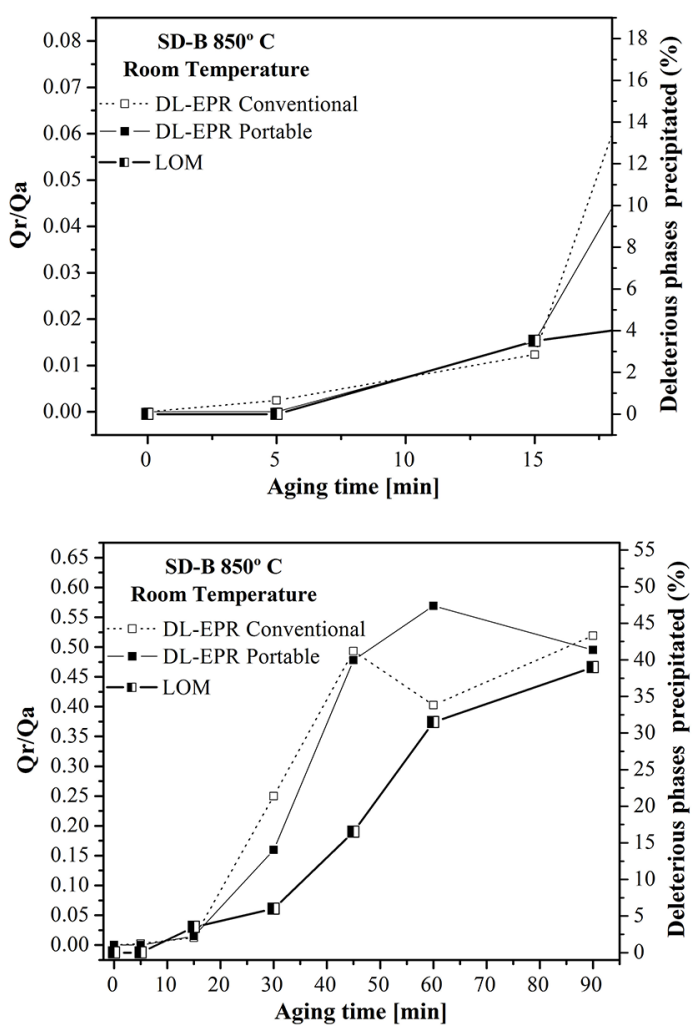

Figure 13. Qr/Qa ratios and deleterious phases precipitated percentage against aging time in SD-B samples aged at $850^{\circ} \mathrm{C}$ till (a) 15 minutes and (b) 90 minutes.

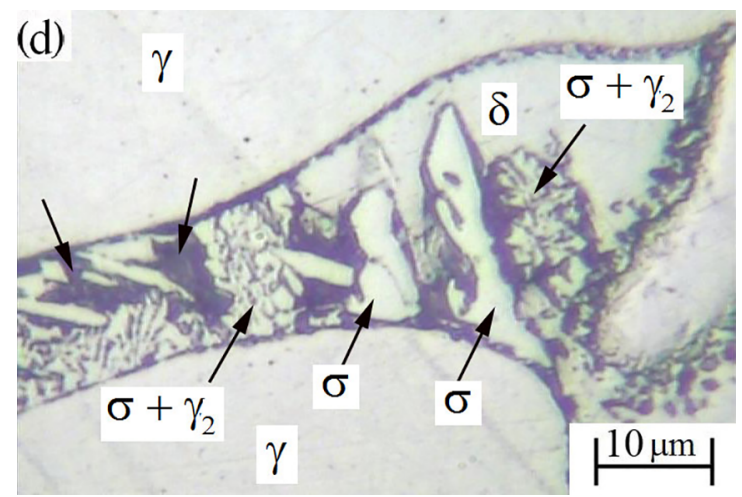

Figure 14. Microstructure obtained after portable DL-EPR test performed at room temperature in SD-B material aged at $850^{\circ} \mathrm{C}$ for 45 minutes.

\section{Conclusions}

This work applied nondestructive double loop electrochemical potentiodynamic reactivation (DL-EPR) to detect and quantify the microstructural degradation of superduplex stainless steels (SDSS). The main conclusions are:

- An adequate test solution $2.5 \mathrm{M} \mathrm{H}_{2} \mathrm{SO}_{4}+0.02 \mathrm{M}$ $\mathrm{KSCN}+1.0 \mathrm{M} \mathrm{NaCl}$ allows to detect small amounts of deleterious phases precipitated in different aging 
conditions by portable and non-destructive DL-EPR at room temperature.

- The portable cell designed shows potential use to characterize deleterious phases precipitation of SDSS in situ.

- The degree of sensitization values Ir/Ia and Qr/ Qa were very similar in samples aged at 800 and $850^{\circ} \mathrm{C}$ for different periods of time.

- The results obtained with conventional and portable DL-EPR tests show the same behavior in specimens aged at $800^{\circ} \mathrm{C}$ and $850^{\circ} \mathrm{C}$. The degree of sensitization against the amount of deleterious phases precipitated showed the same trend in tests performed with two SDSS with different grain sizes.

- The influence of grain size on the kinetics of deleterious phases precipitation was confirmed by portable DL-EPR tests.

\section{Acknowledgements:}

The authors acknowledge the Brazilian research agencies (CAPES, FAPERJ and CNPq) for financial support.

\section{References}

1. Gunn RN, ed. Duplex Stainless Steels. Microstructure, Properties and Applications. Cambridge: Abington Publishing; 2003

2. Pardal JM, Tavares SSM, Cindra Fonseca MP, Silva MR, Ferreira MLR. Study of deleterious phase precipitation under continuous cooling of superduplex stainless steel UNS S32750. Materials Science and Technology. 2012;28(3):295-302. DOI: 10.1179/1743284711Y.0000000040

3. Chen TH, Yang JR. Effects of solution treatment and continuous cooling on $\sigma$-phase precipitation in a 2205 duplex stainless steel. Materials Science and Engineering: A. 2001;311(1-2):28-41. DOI: 10.1016/S0921-5093(01)00911-X

4. Pardal JM, Tavares SSM, Cindra Fonseca M, Souza JA, Côrte RRA, Abreu HFG. Influence of the grain size on deleterious phase precipitation in superduplex stainless steel UNSS32750. Materials Characterization. 2009;60(3):165-172. DOI: 10.1016/j. matchar.2008.08.007
5. Pardal JM, Tavares SSM, Cindra Fonseca MP, De Souza JA, Loureiro A, Moura EP. Modeling of deleterious phase precipitation during isothermal treatments in superduplex stainless steel. Journal of Materials Science. 2010;45:616-623. DOI: $10.1007 / \mathrm{s} 10853-009-3935-4$

6. Lopez N, Cid M, Puiggali M, Azkarate I, Pelayo A. Application of double loop electrochemical potentiodynamic reactivation test to austenitic and duplex stainless steels. Materials Science and Engineering: A. 1997;229(1-2):123-128. DOI: 10.1016/ S0921-5093(97)00008-7

7. Assis KS, Rocha AC, Margarit-Mattos ICP, Serra FAS, Mattos OR. Practical aspects on the use of on-site Double Loop Electrochemical Potentiodynamic Reactivation Technique (DL-EPR) for Duplex Stainless Steel. Corrosion Science. 2013;74:250-255. DOI: 10.1016/j.corsci.2013.04.050

8. Barreto ADG, Andrade TC, Silva CC, Miranda HC. Utilização do equipamento de ensaio EPR-DL de campo na detecção de fase sigma. Tecnologia em Metalurgia, Materiais e Mineração. 2014;11(2):146-154. DOI: 10.4322/tmm.2014.022

9. Pardal JM, Tavares SSM, Souza GC, Cindra Fonseca MP, Ponzio EA, Macedo MCS. Influence of Deleterious Phases Precipitation in the Corrosion Resistance Measured by Double Loop Electrochemical Polarization Reactivation Test in Superduplex Stainless Steel. Materials Research. 2015;18(4):740-747. DOI: 10.1590/1516-1439.001614

10. The University of Texas Health Science Center (UTHSCSA). Image Tool Version 3.0. Department of Dental Diagnostic Science at The University of Texas Health Science Center (UTHSCSA), San Antonio, Texas. Available from: $<$ http://compdent.uthscsa.edu/dig/itdesc.html $>$. Access in: $20 / 09 / 2017$

11. British Standards Institution - BSI. BS EN ISO 12732: Corrosion of metals and alloys. Electrochemical potentiokinetic reactivation measurement using the double loop method (based on Cihal's method). London: BSI; 2008.

12. Ennes CSB. Caracterização Microestrutural Não Destrutiva da Degradação de um Espelho de Gerador de Gás Inerte Construido em AISI 310S. [Master's dissertation]. Niterói: Universidade Federal Fluminense; 2013. 